\title{
Antibacterial and Antioxidant Activities of Ursolic Acid and Derivatives
}

Patrícia G.G. do Nascimento ${ }^{1}$, Telma L.G. Lemos ${ }^{1, *}$, Ayla M.C. Bizerra ${ }^{1}$, Ângela M.C. Arriaga ${ }^{1}$, Daniele A. Ferreira ${ }^{1}$, Gilvandete M.P. Santiago ${ }^{2}$, Raimundo Braz-Filho ${ }^{3}$ and José Galberto M. Costa ${ }^{4}$

1 Departamento de Química Orgânica e Inorgânica, Universidade Federal do Ceará, Fortaleza-CE 60451-970, Brazil; E-Mails: georgina.quimica@gmail.com (P.G.G.N.); aylamarcia@yahoo.com.br (A.M.C.B.); angelamcarriaga@yahoo.com.br (A.M.C.A.); dafufc@yahoo.com.br (D.A.F.)

2 Departamento de Farmácia, Universidade Federal do Ceará, Fortaleza-CE 60430-370, Brazil; E-Mail: gil@ufc.br

3 Laboratório de Ciências Químicas (LCQUI)-CCT-UENF/PPGQO-DEQUIM-UFRRJ, Campos dos Goytacazes-RJ 28013-602, Brazil; E-Mail: braz@uenf.br

4 Laboratório de Pesquisa de Produtos Naturais, Universidade Regional do Cariri, Crato-CE 63105-000, Brazil; E-Mail: galberto.martins@gmail.com

* Author to whom correspondence should be addressed; E-Mail: tlglemos@yahoo.com.br; Tel.: +55-85-3366-9366; Fax: +55-85-3366-9978.

Received: 7 November 2013; in revised form: 11 December 2013 / Accepted: 20 December 2013 / Published: 21 January 2014

\begin{abstract}
Ursolic acid, an important bioactive compound, was isolated from ethanol extract of aerial parts of Sambucus australis. In order to develop bioactive ursolic acid derivatives, two semi-synthetic compounds were obtained through modification at C-3. The antibacterial activity of the ursolic acid and its derivatives was investigated. The microdilution method was used for determination of the minimal inhibitory concentration (MIC), against twelve bacterial strains. The influence of ursolic acid and its derivatives on the susceptibility of some bacterial pathogens to the aminoglycosides antibiotics neomycin, amikacin, kanamycin and gentamicin was evaluated. The most representative synergistic effect was observed by $3 \beta$-formyloxy-urs-12-en-28-oic acid at the concentration of $64 \mu \mathrm{g} / \mathrm{mL}$ in combination with kanamycin against Escherichia coli (27), a multidrugresistant clinical isolate from sputum, with reduction of MIC value from $128 \mu \mathrm{g} / \mathrm{mL}$ to
\end{abstract}


$8 \mu \mathrm{g} / \mathrm{mL}$. Ursolic acid and its derivatives were examined for their radical scavenger activity using the DPPH assay, and showed significant activity.

Keywords: Sambucus australis; ursolic acid; antioxidant activity; antibacterial activity

\section{Introduction}

Ursolic acid (1), an ursane-type pentacyclic triterpene, is a constituent of certain medicinal herbs and is also found in fruits [1]. This triterpenoid is the major secondary metabolite isolated from the ethanol extract of aerial parts of Sambucus australis Cham. \& Schltdl (Caprifoliaceae), a shrub, popularly known as "sabugueiro".

It is well known to possess a wide range of biological activities including anti-inflammatory [2], anticancer [3], hypoglycemic [4], antiprotozoal against Plasmodium falciparum [5], antioxidant [1,6,7], antibacterial [8], and prevents abdominal adiposity [9]. The antibacterial properties of pentacyclic triterpenes and their derivatives have been extensively studied [10-13], and the activity of these compounds also resides in their potential to enhance bacterial susceptibility to other compounds, including antibiotics [14].

Antibiotic resistance is a serious problem in the area of public health. The search for new therapeutic agents that can help patients infected by bacterial agents is a challenge for all professionals in the field. The use of natural products is an alternative that can produce good results.

The production of oxygen and free radicals in the body, probably involves the development of many diseases such as inflammation, cancer, rheumatoid arthritis, Parkinson's and Alzheimer's diseases [15]. The natural antioxidants cause less toxic side effect and can provide protection against oxidative degradation by decrease free radicals in cosmetic, pharmaceutical, and food.

The aim of the present study was to prepare derivatives of ursolic acid (1), and to investigate the antibacterial and scavenger activities using DPPH assay of one $\mathbf{1}$ and its derivatives $\mathbf{1 a}$ and $\mathbf{1 b}$. The influence of the compounds $\mathbf{1}, \mathbf{1 a}$ and $\mathbf{1 b}$ on the susceptibility of several Gram-positive and Gram-negative bacteria towards the aminoglycoside antibiotics neomycin, amikacin, kanamycin and gentamicin was also evaluated.

\section{Results and Discussion}

\subsection{Synthesis}

Ethanol extract of the aerial parts of $S$. australis (SAEtOH) was fractionated and purified by classical chromatographic methods to isolate the triterpenoid ursolic acid (1) [16]. In order to develop bioactive ursolic acid derivatives, two semi-synthetic compounds were obtained through modification at C-3. The structural changes involving the hydroxyl group were acetylation and formylation (Scheme 1). The structures of all compounds were established by $1 \mathrm{D}{ }^{1} \mathrm{H}$ and ${ }^{13} \mathrm{C}$ (and DEPT) and 2D HSQC and HMBC NMR spectral data and by comparing their spectroscopy data with the literature [16-18].

The treatment of (1) with acetic anhydride and pyridine at room temperature afforded $3 \beta$-acetoxyurs-12-en-28-oic acid (1a) in quantitative yield. The ${ }^{1} \mathrm{H}-\mathrm{NMR}$ spectrum of 1a showed a signal at $\delta_{\mathrm{H}}$ 
2.05 typical of hydrogen of acetyl group. The presence of this group was further confirmed by the appearance of the signal at $\delta_{\mathrm{C}} 170.9$ in the ${ }^{13} \mathrm{C}$ - NMR spectrum [17]. Analysis of the ${ }^{1} \mathrm{H}-\mathrm{NMR}$ spectrum of $3 \beta$-formiloxy-urs-12-en-28-oic acid (1b) showed a signal at $\delta_{\mathrm{H}} 8.12$ for the formyl group confirmed by the presence of a signal at $\delta_{\mathrm{C}} 161.3$ attributed to a carbonyl [18].

Scheme 1. Synthesis of ursolic acid derivatives.



Reagents and Conditions: (a) $\mathrm{Ac}_{2} \mathrm{O}$, pyridine/rt/24 h; (b) $\mathrm{HCO}_{2} \mathrm{H}$, perchloric acid/60 ${ }^{\circ} \mathrm{C} / 4 \mathrm{~h}$.

\subsection{Antimicrobial Activity and Evaluation of the Modulatory Activity by Direct Contact}

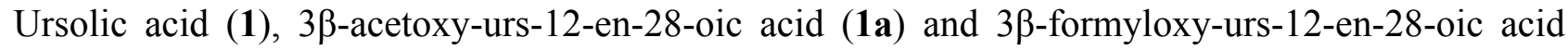
(1b) were tested for antibacterial activity against twelve bacterial strains (different strains of Staphylococcus aureus, Bacillus cereus, two strains of Escherichia coli, Pseudomonas aeruginosa, Aeromonas caveae, Klebsiella pneumoniae, Shigella flexneri, Vibrio colareae and Listeria monocytogenes), by employing the microdilution method. The corresponding minimum inhibitory concentration (MIC) values of (1), (1a) and (1b) are shown in Table 1.

Although the antibacterial activity of ursolic acid (1) against several bacterial strains has been reported in the literature [8,10-12], in our case compound 1 showed activity against six bacterial strains, and the best result was found against $S$. aureus (ATCC 6538), with a MIC value of $32 \mu \mathrm{g} / \mathrm{mL}$. Ursolic acid (1) was also effective against E. coli (ATCC 25922), K. pneumoniae and S. flexneri with a MIC value of $64 \mu \mathrm{g} / \mathrm{mL}$ in the three cases.

$3 \beta$-Acetoxy-urs-12-en-28-oic acid (1a) showed significant activity (in terms of clinical MIC $\leq$ $1,024 \mu \mathrm{g} / \mathrm{mL}$ ) against all tested strains except for S. aureus (ATCC 12624). The best results were found against $E$. coli (ATCC 25922) and $S$. flexneri with a MIC value of $32 \mu \mathrm{g} / \mathrm{mL}$ in both cases, $K$. pneumoniae and $S$. aureus (ATCC 6538) with MIC values of $64 \mu \mathrm{g} / \mathrm{mL}$ and $128 \mu \mathrm{g} / \mathrm{mL}$, respectively (Table 1). The literature reports activity against Streptococcus pneumoniae (ATCC 6305) for compound (1a) [11], however, this is the first report on the antibacterial activity of the derivative 1a on the bacterial strains used.

In the present study, 3ß-formyloxy-urs-12-en-28-oic acid (1b) presented significant activity from a clinical point of view against ten evaluated bacterial strains, with emphasis against $S$. aureus (ATCC 
6538), A. caveae and L. monocytogenes with MIC values of $256 \mu \mathrm{g} / \mathrm{mL}$, and $K$ pneumoniae and $S$. flexneri with MIC values of $128 \mu \mathrm{g} / \mathrm{mL}$ (Table 1).

Table 1. Values of the minimal inhibitory concentration (MIC) of compounds $\mathbf{1}, \mathbf{1 a}$ and $\mathbf{1 b}$.

\begin{tabular}{lccc}
\hline \multirow{2}{*}{ Bacterial strains } & \multicolumn{3}{c}{ MIC $(\boldsymbol{\mu g} / \mathbf{m L})$} \\
\cline { 2 - 4 } & $\mathbf{1}$ & $\mathbf{1 a}$ & $\mathbf{1 b}$ \\
\hline Staphylococcus aureus (ATCC 12692) & $\geq 1024$ & 256 & 512 \\
Staphylococcus aureus (ATCC 12624) & $\geq 1024$ & $\geq 1024$ & $\geq 1024$ \\
Staphylococcus aureus (ATCC 6538) & 32 & 128 & 256 \\
Bacillus cereus (ATCC 33018) & $\geq 1024$ & 512 & 512 \\
Escherichia coli (ATCC 25922) & 64 & 32 & 512 \\
Escherichia coli (ATCC 27) & 512 & 256 & 512 \\
Pseudomonas aeruginosa (ATCC 15442) & 512 & 512 & 512 \\
Aeromonas caveae (ATCC 15468) & $\geq 1024$ & 256 & 256 \\
Klebsiella pneumoniae (ATCC 10031) & 64 & 64 & 128 \\
Shigella flexneri (ATCC 12022) & 64 & 32 & 128 \\
Vibrio colareae (ATCC 15748) & $\geq 1024$ & 512 & $\geq 1024$ \\
Listeria monocytogenes (ATCC 19117) & $\geq 1024$ & 256 & 256 \\
\hline
\end{tabular}

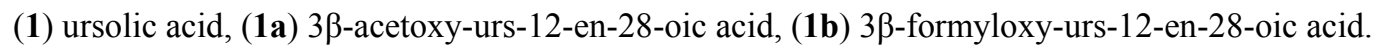

Interestingly, among all evaluated bacterial strains in this study, S. aureus (ATCC 12624) was the most resistant to the tested compounds $\mathbf{1}, \mathbf{1 a}$ and $\mathbf{1 b}$.

The effects on the MIC values of the association of compounds $\mathbf{1}$, $\mathbf{1 a}$ and $\mathbf{1 b}$ with aminoglycoside antibiotics are shown in Table 2. In these assays the compounds that showed MIC $\leq 1024 \mu \mathrm{g} / \mathrm{mL}$ in the MIC determination were used.

Table 2 indicate a synergism between ursolic acid (1) and the aminoglycoside antibiotics in almost all microorganisms, except for gentamicin and amikacin against E. coli (ATCC 25922), and kanamycin against $P$. aeruginosa and $K$. pneumoniae. Ursolic acid (1) was found to enhance the susceptibility of Staphylococcus aureus, Staphylococcus epidermidis and Listeria monocytogenes to the $\beta$-lactam antibiotics ampicilin and oxacilin [14], but there is no report in the literature about this compound acting synergistically with the aminoglycoside antibiotics neomycin, amikacin, kanamycin and gentamicin.

The association of $3 \beta$-acetoxy-urs-12-en-28-oic acid (1a) with the aminoglycoside antibiotics increased the effect of these antibiotics against the strains evaluated; thus 1a may be considered an excellent enhancer of the mechanism of action of these aminoglycoside antibiotics.

The association of $3 \beta$-formyloxy-urs-12-en-28-oic acid (1b) with the aminoglycoside antibiotics showed synergistic effects against several microorganisms. It is also possible to demonstrate that there was no potential interference on the activity of gentamicin against B. cereus and $S$. aureus (ATCC

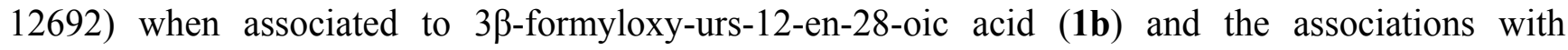
amikacin against $K$. pneumoniae and kanamycin against $L$. monocytogenes. 


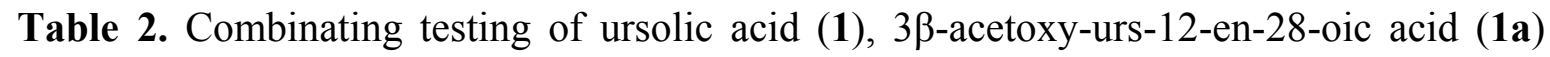
and $3 \beta$-formiloxy-urs-12-en-28-oic acid (1b) plus neomycin, amikacin, kanamycin and gentamicin against bacterial strains.

\begin{tabular}{|c|c|c|c|c|c|}
\hline \multirow{2}{*}{ Bacterial strains } & \multirow{2}{*}{$\begin{array}{c}\text { Combination tested } \\
\text { Antibiotic }+ \text { Substance }(\mu \mathrm{g} / \mathrm{mL})\end{array}$} & \multicolumn{4}{|c|}{$\operatorname{MIC}(\mu \mathrm{g} / \mathrm{mL})$} \\
\hline & & Neomycin & Amikacin & Kanamycin & Gentamicin \\
\hline \multirow[t]{3}{*}{ S. aureus 12692} & $*$ & 128 & 64 & 64 & 128 \\
\hline & 1a (32) & 16 & 4 & 8 & 32 \\
\hline & $1 b(64)$ & 64 & 32 & 16 & 128 \\
\hline \multirow[t]{4}{*}{ S. aureus 6538} & $*$ & 128 & 128 & 64 & 64 \\
\hline & $1(4)$ & 18 & 32 & 16 & 4 \\
\hline & 1a (16) & 16 & 32 & 16 & 16 \\
\hline & $1 b(32)$ & 32 & 64 & 32 & 16 \\
\hline \multirow[t]{3}{*}{ B. cereus 33018} & $*$ & 128 & 128 & 64 & 64 \\
\hline & 1a (64) & 64 & 32 & 8 & 16 \\
\hline & $1 \mathrm{~b}(64)$ & 64 & 64 & 32 & 64 \\
\hline \multirow[t]{4}{*}{ E. coli 25922} & $*$ & 128 & 64 & 128 & 64 \\
\hline & $1(8)$ & 32 & 64 & 64 & 64 \\
\hline & $\mathbf{1 a}(4)$ & 32 & 32 & 16 & 16 \\
\hline & $1 \mathrm{~b}(64)$ & 64 & 32 & 64 & 32 \\
\hline \multirow[t]{4}{*}{ E. coli 27} & $*$ & 64 & 128 & 128 & 64 \\
\hline & $1(8)$ & 4 & 32 & 16 & 32 \\
\hline & 1a (32) & 16 & 32 & 32 & 8 \\
\hline & $1 b(64)$ & 32 & 16 & 8 & 8 \\
\hline \multirow[t]{4}{*}{ P. aeruginosa 15442} & $*$ & 128 & 128 & 64 & 32 \\
\hline & $1(64)$ & 64 & 32 & 64 & 16 \\
\hline & 1a (64) & 64 & 32 & 16 & 4 \\
\hline & $1 \mathbf{b}(64)$ & 32 & 32 & 16 & 8 \\
\hline \multirow[t]{3}{*}{ A. caveae 15468} & $*$ & 64 & 128 & 128 & 128 \\
\hline & 1a (32) & 8 & 16 & 32 & 32 \\
\hline & $1 \mathrm{~b}(64)$ & 16 & 64 & 32 & 32 \\
\hline \multirow[t]{4}{*}{ K. pneumonia 10031} & * & 256 & 64 & 64 & 128 \\
\hline & $1(8)$ & 128 & 32 & 64 & 16 \\
\hline & $\mathbf{1 a}(8)$ & 64 & 32 & 16 & 64 \\
\hline & $1 \mathbf{b}(16)$ & 128 & 64 & 32 & 64 \\
\hline \multirow[t]{4}{*}{ S. flexneri 12022} & $*$ & 512 & 128 & 64 & 64 \\
\hline & $1(8)$ & 64 & 32 & 16 & 16 \\
\hline & $\mathbf{1 a}(4)$ & 256 & 64 & 16 & 8 \\
\hline & $1 \mathbf{b}(16)$ & 128 & 32 & 16 & 32 \\
\hline \multirow[t]{3}{*}{ L. monocytogenes 19117} & $*$ & 128 & 128 & 64 & 64 \\
\hline & 1a (32) & 16 & 32 & 32 & 8 \\
\hline & $1 \mathbf{b}(32)$ & 32 & 64 & 64 & 16 \\
\hline \multirow[t]{2}{*}{ V. colareae 15748} & $*$ & 64 & 32 & 128 & 128 \\
\hline & 1a (64) & 16 & 4 & 16 & 32 \\
\hline
\end{tabular}

* only antibiotics. 


\subsection{Antioxidant Activity}

Compounds 1 and 1a showed antioxidant activity by inhibiting DPPH. The compounds strongly scavenged DPPH radical, with $\mathrm{IC}_{50}$ values of $5.97 \times 10^{-2} \pm 1 \times 10^{-3}$ and $0.73 \pm 9.3 \times 10^{-2} \mathrm{mg} / \mathrm{mL}$, respectively. Trolox and Vitamin $\mathrm{C}$, used as positive controls, showed $\mathrm{IC}_{50}$ values of $2.6 \times 10^{-3} \pm$ $2.3 \times 10^{-4}$ and $4.3 \times 10^{-2} \pm 1.9 \times 10^{-2} \mathrm{mg} / \mathrm{mL}$, respectively (Table 3). Compound $\mathbf{1 b}$ was inactive in the DPPH assay.

Table 3. $\mathrm{IC}_{50}$ values of ursolic acid (1) and derivatives (1a and $\left.\mathbf{1 b}\right)$.

\begin{tabular}{cc}
\hline Samples & $\mathbf{I C}_{\mathbf{5 0}}(\mathbf{m g} / \mathbf{m L})$ \\
\hline $\mathbf{1}$ & $5.97 \times 10^{-2} \pm 1 \times 10^{-3}$ \\
$\mathbf{1 a}$ & $0.73 \pm 9.3 \times 10^{-2}$ \\
$\mathbf{1 b}$ & not active \\
Trolox & $2.6 \times 10^{-3} \pm 2.3 \times 10^{-4}$ \\
Vitamin C & $4.3 \times 10^{-2} \pm 1.9 \times 10^{-2}$ \\
\hline
\end{tabular}

\section{Experimental}

\subsection{General}

Melting points were determined on a digital Mettler Toledo FP82HT apparatus and are uncorrected. The IR spectra were measured in KBr pellets using a Perkin-Elmer FT-IR Spectrum 1000. A Bruker ${ }^{\circledR}$ Avance DRX 500 and a Bruker ${ }^{\circledR}$ Avance DPX 300 spectrometers, operating at $500 \mathrm{MHz}$ and $300 \mathrm{MHz}$ for ${ }^{1} \mathrm{H}-\mathrm{NMR}$, and $125 \mathrm{MHz}$ and $75 \mathrm{MHz}$ for ${ }^{13} \mathrm{C}$-NMR were used for experiments $1 \mathrm{D}$ and $2 \mathrm{D}$ with chemical shifts given in ppm. The spectra were run using $\mathrm{CDCl}_{3}$ and pyridine- $d_{5}$ as the solvent. Chemical shifts, measured on the $\delta$ scale. The absorptions in the region of the ultraviolet (UV) visible were obtained on a Varian Cary 50 Conc spectrophotometer. The low resolution mass spectra were obtained by electron impact at $70 \mathrm{eV}$ spectrometer with Shimadzu a QP 5000, DI-50 instrument. Silica gel 60 (70-230 mesh) was used for column chromatography, and thin layer chromatography (TLC) was performed on precoated silica gel $\mathrm{G}_{60} \mathrm{~F}_{254}$ by detection by spraying with vanillin in perchloric acid/ethanol. All solvents used for chromatography were from Synth. The microbiological culture media were purchased from Fundação Oswaldo Cruz-FIOCRUZ (Rio de Janeiro, Brazil).

\subsection{Plant Material}

The aerial parts of Sambucus australis were collected in Guaramiranga County, State of Ceará, northeast Brazil. A voucher specimen (\#EAC15002) has been deposited at the Herbarium Prisco Bezerra, Department of Biology, Federal University of Ceará, Brazil.

\subsection{Extraction and Isolation}

Aerial parts including leaves and flowers of Sambucus australis were extracted with ethyl acetate $(1,000 \mathrm{~g} / 1,500 \mathrm{~mL})$ for $72 \mathrm{~h}$ at $25{ }^{\circ} \mathrm{C}$, followed by ethanol $(1,000 \mathrm{~g} / 5,000 \mathrm{~mL})$ for $72 \mathrm{~h}$ at $25{ }^{\circ} \mathrm{C}$ to yield: SAEtOAc, $(3.9 \mathrm{~g}, 0.39 \%)$ and SAEtOH, $(1.0 \mathrm{~g}, 0.1 \%)$, respectively. The ethanol extract 
$(\mathrm{SAEtOH})(1.0 \mathrm{~g})$ was chromatographed on a silica gel column running a gradient of $100 \%$ ethyl acetate to $100 \%$ methanol. The fraction eluted with $100 \%$ ethyl acetate yield a solid material, which was further recrystallized in ethyl acetate to afforded ursolic acid (1, $180 \mathrm{mg}, 18 \%)$; White solid; m.p. 279.0-281.1 ${ }^{\circ} \mathrm{C}$; FTIR $\left(\mathrm{cm}^{-1}\right): 3407,2924,2855,1686,1456,1387 . \mathrm{MS}$ (EI): $\mathrm{m} / z$ (\%) 456 (0.2), 248 (100), 203 (43), 133 (37), 44(83). ${ }^{13} \mathrm{C}-\mathrm{NMR}\left(\mathrm{C}_{5} \mathrm{D}_{5} \mathrm{~N}\right) \delta$ ppm: $37.98(\mathrm{C}-1), 28.65(\mathrm{C}-2), 78.62(\mathrm{C}-3)$, 39.85) (C-4), 56.32 (C-5); 19.44 (C-6), 34.11 (C-7), 39.45 (C-8), 48.59 (C-9), 37.78 (C-10), 24.06 (C-11), 126.14 (C-12), 139.75 (C-13), 42.51 (C-14), 28.65 (C-15 ), 25.45 (C-16), 48.54 (C-17), 54.04 (C-18), 40.02 (C-19), 39.94 (C-20), 31.60 (C-21), 37.96 (C-22), 29.35 (C-23), 15.19 (C-24), 15.25 (C-25), 18.06 (C-26), 26.69 (C-27), 180.34 (C-28), 18.06 (C-29), 21.94 (C-30) in agreement with the literature [16].

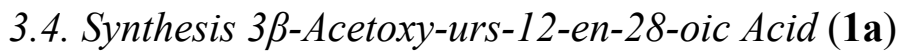

To a solution of ursolic acid $(\mathbf{1}, 50 \mathrm{mg}, 0.109 \mathrm{mmol})$ in pyridine $(0.5 \mathrm{~mL})$ was added $\mathrm{Ac}_{2} \mathrm{O}(2 \mathrm{~mL}$, $1.05 \mathrm{mmol}$ ). After stirring at room temperature for $24 \mathrm{~h}$, the reaction mixture was quenched with saturated $\mathrm{CuSO}_{4}(20 \mathrm{~mL})$ and extracted with EtOAc $3 \times 30 \mathrm{~mL}$. The combined extracts were washed with $\mathrm{H}_{2} \mathrm{O}$ and brine, dried over anhydrous $\mathrm{Na}_{2} \mathrm{SO}_{4}$, and evaporated under reduced pressure. The residue was purified by column chromatography on silica gel with $n$-hexane/ethyl acetate $=3: 7(\mathrm{v}: \mathrm{v})$ to give a white solid; Yield 75\% (40.0 mg); m.p. 175.3-178.1 ${ }^{\circ} \mathrm{C}$. FTIR $\left(\mathrm{cm}^{-1}\right): 3215,2924,1722,1447$, 1366; ${ }^{13} \mathrm{C}-\mathrm{NMR}\left(\mathrm{CDCl}_{3}\right) \delta$ ppm: C-1 (36.94), C-2 (24.25), C-3 (81.17); C-4 (37.91); C-5 (55.51), C-6 (18.37), C-7 (33.24), C-8 (39.71), C-9 (47.68), C-10 (37.13), C-11 (23.50), C-12 (125.93), C-13 (138.18), C-14 (42.10), C-15 (28.20), C-16 (23.78), C-17 (48.18); C-18 (52.71), C-19 (39.23), C-20 (39.04), C-21 (30.81), C-22 (38.47), C-23 (28.29), C-24 (17.23), C-25 (15.60), C-26 (16.91), C-27 (23.80), C-28 (184.15), C-29 (17.33), C-30 (21.51); EIMS ( $\mathrm{m} / \mathrm{z}): 498\left(0.1 \%, \mathrm{M}^{+}\right), 248(17 \%), 43$ $(82 \%)$ in agreement with the literature [17].

\subsection{Synthesis 3 $\beta$-Formiloxy-urs-12-en-28-oic Acid(1b)}

A solution of ursolic acid $(\mathbf{1}, 50 \mathrm{mg}, 0.109 \mathrm{mmol})$ in $89.9 \% \mathrm{HCO}_{2} \mathrm{H}(1.5 \mathrm{~mL})$ and $70 \%$ perchloric acid ( 6 drops) was heated in an $\mathrm{H}_{2} \mathrm{O}$ bath at $60{ }^{\circ} \mathrm{C}$ for $4 \mathrm{~h}$. The solution was removed from the bath and allowed to cool to about $40{ }^{\circ} \mathrm{C}$. $\mathrm{Ac}_{2} \mathrm{O}$ was then added dropwise while the temperature was maintained between 55 and $60{ }^{\circ} \mathrm{C}$ until a large quantity of bubbles appeared ( $1 \mathrm{~mL}$ of $\mathrm{Ac}_{2} \mathrm{O}$ was required). The solution was then cooled to room temperature and poured into $10 \mathrm{ml} \mathrm{of} \mathrm{H}_{2} \mathrm{O}$, with stirring [19]. The precipitate was filtered under vacuum, washed with $\mathrm{H}_{2} \mathrm{O}$, and dried to give a white solid; Yield $28 \%$ (23.1 mg); m.p. $117.3-119.4{ }^{\circ} \mathrm{C}$; FTIR $\left(\mathrm{cm}^{-1}\right): 2924,1718,1688,1458,1369 ;{ }^{13} \mathrm{C}-\mathrm{NMR}\left(\mathrm{CDCl}_{3}\right) \delta$ ppm: 38.53 (C-1), 23.55 (C-2), 81.35 (C-3), 37.92 (C-4), 55.57 (C-5), 18.46 (C-6), 33.11 (C-7), 39.83 (C-8), 47.75 (C-9), 37.18 (C-10), 23.97 (C-11), 125.94 (C-12), 138.27 (C-13), 42.25 (C-14), 29.94 (C-15), 24.33 (C-16), 48.22 (C-17), 52.84 (C-18), 39.10 (C-19), 39.29 (C-20), 30.86 (C-21), 36.96 (C-22), 28.27 (C-23), 21.40 (C-24), 15.75 (C-25), 16.94 (C-26), 23.84 (C-27), 183.18 (C-28), 17.25 (C-29), 17.30 (C-30) in agreement with the literature [18]. 


\subsection{Antibacterial Activity and Minimal Inhibitory Concentration}

The antibacterial activity of the ursolic acid and its derivatives were investigated employing a microdilution method, recommended by National Committee for Clinical and Laboratory Standards M7-A6 [20]. In tests were used eight standard strains of Gram (-) and four Gram (+), and two clinical isolates of multidrug-resistant Escherichia coli (27) (from sputum) and Staphylococcus aureus (6538) of the surgical wound. The brain heart infusion (BHI 3.8\%) broth was used for the bacterial growth (24 h, $35 \pm 2{ }^{\circ} \mathrm{C}$ ). The inoculum was an overnight culture of each bacterial species in the BHI broth diluted in the same medium to a final concentration of approximately $1 \times 10^{8} \mathrm{CFU} / \mathrm{mL}(0.5 \mathrm{NTU}-\mathrm{McF}$ arland scale). After this, the suspension was dilluted to $1 \times 10^{6} \mathrm{CFU} / \mathrm{mL}$ in $10 \% \mathrm{BHI}$. A total of $100 \mu \mathrm{L}$ of each dilution was distributed in 96-well plates plus substance, achieving $5 \times 10^{5} \mathrm{CFU} / \mathrm{mL}$ as the final concentration of the inoculums [21-23].

The initial solution of the ursolic acid and its derivatives were performed using $10 \mathrm{mg}$ of each extract dissolved in $1 \mathrm{~mL}$ of dimethyl sulfoxide (DMSO) to obtain an initial concentration of $10 \mathrm{mg} / \mathrm{mL}$. From this concentration, several dilutions were made in distilled water in order to obtain a stock solution of $1,024 \mu \mathrm{g} / \mathrm{mL}$. Further serial dilutions were performed by the addition of the BHI broth to reach a final concentration in the range of $8-512 \mu \mathrm{g} / \mathrm{mL}$ ). All experiments were performed in triplicate and the microdilution trays were incubated at $35 \pm 2{ }^{\circ} \mathrm{C}$ for $24 \mathrm{~h}$. The antibacterial activity was detected using a colorimetric method by adding $25 \mu \mathrm{L}$ of the resauzurin staining $(0.01 \%)$ aqueous solution in each well at the end of the incubation period [24]. The minimal inhibitory concentration (MIC) was defined as the lowest extract concentration able to inhibit the bacteria growth, as indicated by resauzurin staining (dead bacterial cells are not able to change the staining color by visual observation-blue to red).

\subsection{Evaluation of the Modulatory Activity by Direct Contact}

In order to evaluate of the ursolic acid and its derivatives as modulators of antibiotic resistance, the MICs values of aminoglycosides antibiotics neomycin, kanamycin, amikacin, and gentamicin against the analyzed strains were determined in the presence or absence of the extracts using the microdutiltion test. Subinhibitory concentrations (MIC 1/8) in 10\% BHI were used. The antibiotic solutions $(1024 \mu \mathrm{g} / \mathrm{mL})$ were prepared in distillated water for use on the same day. A total of $100 \mu \mathrm{L}$ of the antibiotic solution, using serial dilutions (1:2), was added to the wells containing $10 \% \mathrm{BHI}$ and the diluted bacterial suspension (1:10). Microplates were incubated at $35 \pm 2{ }^{\circ} \mathrm{C}$ for $24 \mathrm{~h}$ and the antibacterial activity was determined as described before [25].

\subsection{Antioxidant Activity}

The antioxidant activities of ursolic acid (1), and derivatives $\mathbf{1 a}$ and $\mathbf{1 b}$ were evaluated by measuring the reduction of the free radical 1,1-diphenyl-1-picrylhydrazyl (DPPH). The samples (1.0 to $1000.0 \mu \mathrm{g} / \mathrm{mL}$ ) were dissolved in methanol and then added to a methanol solution of DPPH (60 mM) [26]. After $30 \mathrm{~min}$, the UV absorbance of the resulting solutions was recorded at $\lambda 517 \mathrm{~nm}$. The experiment was performed in triplicate and the average absorption was noted for each concentration. Trolox and Vitamin $\mathrm{C}$ were used as the positive control. The free radical scavenging activity was calculated as a 
percentage inhibition of the DPPH radical by the sample or positive control. The $\mathrm{IC}_{50}$ value is the concentration required to scavenge $50 \% \mathrm{DPPH}$.

\section{Conclusions}

This study showed that ursolic acid (1) and some of its derivatives have significant antibacterial activity against several bacterial species, and that these compounds show synergistic activities with the aminoglycoside antibiotics neomycin, amikacin, kanamycin and gentamicin. These results suggest that Sambucus australis could be a potential natural source of free radical scavengers.

\section{Acknowledgments}

The authors thank the Brazilian agencies CAPES and CNPq for fellowships and financial support.

\section{Author Contributions}

Patricia Nascimento, Ayla Bizerra: chromatography procedures and synthesis of derivatives; Jose G. Costa: antimicrobial activity; Daniela Ferreira: antioxidant activity; R. Braz-Filho: analysis of spectroscopic data; Telma Lemos, Gilvandete Santiago, advisors and mentors; Angela Arriaga: criticism.

\section{Conflicts of Interest}

The authors declare no conflict of interest.

\section{References}

1. Liobikas, J.; Majiene, D.; Trumbeckaite, S.; Kursvietiene, L.; Masteikova, R.; Kopustinskiene, D.M.; Savickas, A.; Bernatoniene, J. Uncoupling and antioxidant effects of ursolic acid in isolated rat heart mitochondria. J. Nat. Prod. 2011, 74, 1640-1644.

2. Ku, C.-M.; Lin, J.-Y. Anti-inflammatory effects of 27 selected terpenoid compounds tested through modulating Th1/Th2 cytokine secretion profiles using murine primary splenocytes. Food Chem. 2013, 141, 1104-1113.

3. Shanmungam, M.K.; Dai, X.; Kumar, A.P.; Tan, B.K.H.; Sethi, G.; Bishayee, A. Ursolic acid in cancer prevention and treatment: Molecular targets, pharmacokinetics and clinical studies. Biochem. Pharmacol. 2013, 85, 1579-1587.

4. Alqahtani, A.; Hamid, K.; Kam, A.; Wong, K.H.; Abdelhak, Z.; Razmovski-Naumovski, V.; Chan, K.; Li, K.M.; Groundwater, P.W.; Li, G.Q. The pentacyclic triterpenoids in herbal medicines and their pharmacological activities in diabetes and diabetic complications. Curr. Med. Chem. 2013, 20, 908-931.

5. Van Baren, C.; Anao, I.; Lira, P.L.; Debenedetti, S.; Houghton, P.; Croft, S.; Martino, V. Triterpenic acids and flavonoids from Satureja parvifolia. Evaluation of their antiprotozoal activity. Z. Naturforsch. C 2006, 61, 189-192.

6. Ali, M.S.; Ibrahim, S.A.; Jalil, S.; Choudhary, M.I. Ursolic acid: A potent inhibitor of superoxides produced in the cellular system. Phytother. Res. 2007, 21, 558-561. 
7. D’Abrosca, B.; Fiorentino, A.; Monaco, P.; Pacifico, S. Radical-scavenging activities of new hydroxylated ursane triterpenes from cv. Annurca Apples. Chem. Biodiv. 2005, 2, 953-958.

8. Acebey-Castellon, I.L.; Voutquenne-Nazabadioko, L.; Mai, H.D.T.; Roseau, N.; Bouthagane, N.; Muhammad, D.; Debar, E.M.; Gangloff, S.C.; Litaudon, M.; Sevenet, T.; et al. Triterpenoid saponins from Symplocos lancifolia. J. Nat. Prod. 2011, 74, 163-168.

9. Rao, V.S.; de Melo, C.L.; Queiroz, M.G.R.; Lemos, T.L.G.; Menezes, D.B.; Melo, T.S.; Santos, F.A. Ursolic Acid, a pentacyclic triterpene from Sambucus australis, prevents abdominal adiposity in mice fed a high-fat diet. J. Med. Food 2011, 14, 1375-1382.

10. Mallavadhani, U.V.; Mahapatra, A.; Jamil, K.; Reddy, P.S. Antimicrobial activity of some pentacyclic triterpenes and their synthesized 3-O-lipophilic chains. Biol. Pharm. Bull. 2004, 27, $1576-1579$.

11. Cunha, W.R.; de Matos, G.X.; Souza, M.G.M.; Tozatti, M.G.; Silva, M.L.A.; Martins, C.H.G.; da Silva, R.; da Silva Filho, A.A. Evaluation of the antibacterial activity of the methylene chloride extract of Miconia ligustroides, Isolated triterpene acids, and ursolic acid derivatives. Pharm. Biol. 2010, 48, 166-169.

12. Wolska, K.I.; Grudniak, A.M.; Fiecek, B.; Kraczkiewicz-Dowjat, A.; Kurek, A. Antibacterial activity of oleanolic and ursolic acids and their derivatives. Cent. Eur. J. Biol. 2010, 5, 543-553.

13. Silva, M.L.; David, J.P.; Silva, L.C.R.C.; Santos, R.A.F.; David, J.M.; Lima, L.S.; Reis, P.S.; Fontana, R. Bioactive oleanane, lupane and ursane triterpene acid derivatives. Molecules 2012, 17, 12197-12205.

14. Kurek, A.; Nadkowska, P.; Pliszka, S.; Wolska, K.I. Modulation of antibiotic resistance in bacterial pathogens by oleanolic acid and ursolic acid. Phytomedicine 2012, 19, 515-519.

15. Bano, T.; Kumar, N.; Dudhe, R. Free radical scavenging properties of pyrimidine derivatives. Org. Med. Chem. Lett. 2012, 34, 1-6.

16. Mahato, S.B.; Kundu, A.P. ${ }^{13}$ C NMR spectra of pentacyclic triterpenoids-A compilation and some salient features. Phytochemistry 1994, 37, 1517-1575.

17. Gnoatto, S.C.B.; Dassonville-Klimpt, A.; Nascimento, S.D.; Galéra, P.; Boumediene, K.; Gosmann, G.; Sonnet, P.; Moslemi, S. Evaluation of ursolic acid isolated from Ilex paraguariensis and derivatives on aromatase inhibition. Eur. J. Med. Chem. 2008, 43, 1865-1877.

18. Tkachev, A.V.; Denisov, A.Y.; Gatilov, Y.V.; Bagryanskaya, I.Y.; Shevtsov, S.A.; Rybalova, T.V. Stereochemistry of hydrogen peroxide-Acetic acid oxidation of ursolic acid and related compounds. Tetrahedron 1994, 50, 11459-11488.

19. Lemos, T.L.G.; Mcchesney, J.D. Utilization of common natural products as synthons: Preparation of progesterone from lithocholic acid. J. Nat. Prod. 1990, 53, 152-156.

20. National Committee for Clinical Laboratory Standards. Methods for Dilution Antimicrobial Susceptibility Tests for Bacteria that Grow Aerobically; Approved Standard-Sixth Edition; CLSI document M7-A6; NCCLS: Wayne, PA, USA, 2003.

21. Hadacek, F.; Greger, H. Testing of antifungal natural products: Methodologies, comparability of results and assay choice. Phytochem. Anal. 2000, 11, 137-147.

22. National Committee for Clinical Laboratory Standards. Performance Standards for Antimicrobial Susceptibility Testing: Twelfth Informational Supplement; CLSI document M100-S12; NCCLS: Wayne, PA, USA, 2002; Volume 22; Number 1. 
23. Viljoen, A.; Vuuren, A.V.; Ernst, E.; Klepser, M.; Demirci, B.; Baser, H.; Vanwyk, B.E. Osmitopsis asteriscoides (Asteraceae) the antimicrobial activity and essential oil composition of a Cape-Dutch remedy. J. Ethnopharmacol. 2003, 88, 137-143.

24. Salvat, A.; Antonnacci, L.; Fortunato, R.H.; Suarez, E.Y.; Godoy, H.M. Screening of some plants from Northern Argentina for their antimicrobial activity. Lett. Appl. Microbiol. 2001, 32, 293-297.

25. Sagdiç, O. Sensitivity of four pathogens pathogenic bacteria to Turkish thyme and oregano hydrosols, Lebensm. Wiss. Technol. 2003, 36, 467-473.

26. Bandeira, P.N.; Fonseca, A.M.; Costa, S.M.O.; Lins, M.U.D.S.; Pessoa, O.D.L.; Monte, F.J.Q.; Nogueira, N.A.P.; Lemos, T.L.G. Antimicrobial and antioxidant activities of the essential oil of resin of Protium heptaphyllum. Nat. Prod. Commun. 2006, 1, 117-120.

Sample Availability: Samples 1, $\mathbf{1 a}$ and $\mathbf{1 b}$ are available from the authors.

(C) 2014 by the authors; licensee MDPI, Basel, Switzerland. This article is an open access article distributed under the terms and conditions of the Creative Commons Attribution license (http://creativecommons.org/licenses/by/3.0/). 